\title{
Effects of omega-3 supplementation on endothelial dysfunction in humans: a systematic review
}

\author{
Efeitos da suplementação de ômega 3 na disfunção endotelial em humanos: \\ uma revisão sistemática
}

Efectos de la suplementación con omega 3 sobre la disfunción endotelial en humanos: una revisión sistemática

Ana Lina de Carvalho Cunha Sales ${ }^{1 *}$, Maísa Guimarães Silva Primo ${ }^{1}$, Juliana Soares Severo $^{1}$, Amanda Suellenn da Silva Santos Oliveira ${ }^{1}$, Thamara Martins Silva ${ }^{1}$, Vitória Ribeiro Mendes $^{1}$, Maria do Carmo de Carvalho e Martins ${ }^{1}$.

\begin{abstract}
Objective: To evaluate the effects of omega- 3 supplementation on endothelial dysfunction in humans, considering the lipid profile, inflammatory and oxidative stress markers. Methods: The search for the articles was carried out on the bases PubMed, Scopus, Cochrane and Web of Science, following the recommendations for Systematic Reviews and Meta-analysis of PRISMA. This study was registered in the International Prospective Register of Systematic Reviews database. After the process of searching and applying the inclusion criteria, 17 articles were selected. Results: The most pronounced effect of omega- 3 supplementation was on reductions in triglycerides, tumor necrosis factor alpha, interleukin 6, pulse wave velocity and increased dilation mediated by the flow of the brachial artery. There were no significant changes in oxidative stress biomarkers and overall nutritional status. Final considerations: Evidence of benefits of omega- 3 in improving dyslipidemia, inflammation and endothelial dysfunction; new intervention research is needed to better elucidate the role of this nutrient in the studied parameters, in addition to establishing effective doses, composition and intervention time for application in clinical practice.
\end{abstract}

Keywords: Omega-3, Endothelium vascular, Lipid metabolism, Dyslipidemias, Supplementation.

\section{RESUMO}

Objetivo: Avaliar os efeitos da suplementação com ômega-3 sobre a disfunção endotelial em humanos, considerando o perfil lipídico, marcadores inflamatório e de estresse oxidativo. Métodos: A busca dos artigos foi realizada nas bases PubMed, Scopus, Cochrane e Web of Science, seguindo as recomendações para Revisões Sistemáticas e Meta-análise do PRISMA. Esse estudo foi registrado no banco de dados International Prospective Register of Systematic Reviews. Após o processo de busca e aplicação dos critérios de inclusão 17 artigos foram selecionados. Resultados: $O$ efeito mais pronunciado da suplementação de ômega-3 fora nas reduções de triglicerídeos, fator de necrose tumoral alfa, interleucina 6 , velocidade de onda de pulso e aumento da dilatação mediada pelo fluxo da artéria braquial. Não houve alterações significativas em biomarcadores de estresse oxidativo e estado nutricional global. Considerações finais: Evidências de benefícios do ômega-3 na melhora da dislipidemia, inflamação e disfunção endotelial; torna-se necessário novas pesquisas de intervenção para melhor elucidar o papel desse nutriente nos parâmetros estudados, além de estabelecer doses, composição e tempo de intervenção eficazes para aplicação na prática clínica.

Palavras-chave: Ômega-3, Endotélio vascular, Metabolismo lipídico, Dislipidemias, Suplementação.

\section{RESUMEN}

Objetivo: Evaluar los efectos de la suplementación con omega-3 sobre la disfunción endotelial en humanos, considerando el perfil lipídico, marcadores inflamatorios y de estrés oxidativo. Métodos: La búsqueda de los artículos se realizó sobre las bases PubMed, Scopus, Cochrane y Web of Science, siguiendo las recomendaciones para Revisiones Sistemáticas y Metanálisis de PRISMA. Este estudio se registró en la base

${ }^{1}$ Federal University of Piauí (UFPI), Teresina - PI. *Email: ana.lina123@gmail.com 
de datos del International Prospective Register of Systematic Reviews. Tras el proceso de búsqueda y aplicación de los criterios de inclusión, se seleccionaron 17 artículos. Resultados: El efecto más pronunciado de la suplementación con omega-3 fue la reducción de los triglicéridos, el factor de necrosis tumoral alfa, la interleucina 6, la velocidad de la onda del pulso y el aumento de la dilatación mediada por el flujo de la arteria braquial. No hubo cambios significativos en los biomarcadores de estrés oxidativo y el estado nutricional general. Consideraciones finales: Evidencia de los beneficios del omega-3 para mejorar la dislipidemia, la inflamación y la disfunción endotelial; Se necesitan nuevas investigaciones de intervención para dilucidar mejor el papel de este nutriente en los parámetros estudiados, además de establecer dosis, composición y tiempo de intervención efectivos para su aplicación en la práctica clínica.

Palabras clave: Omega 3, Endotelio vascular, Metabolismo de los lípidos, Dislipidemias, Suplementación.

\section{INTRODUCTION}

Endothelial dysfunction is the imbalance in the production of mediators that regulate vascular tone, platelet aggregation, coagulation and fibrinolysis (QIAN J e FULTON D, 2013). A healthy endothelium can maintain vasodilation and inhibit platelet aggregation, leukocyte adhesion, and proliferation of smooth muscle cells. There are not enough data to clarify the epidemiology of endothelial dysfunction, but atherosclerosis causes a form of cardiovascular disease, peripheral arterial disease (PAD). According to the American Heart Association 8 million patients in the United States are afflicted with PAD, which is associated with significant morbidity and mortality; prevalence increases with age (ALLEN JD, et al., 2012).

Thus, endothelial dysfunction precedes atherosclerosis, as a long-term consequence of oxidative stress and inflammation in the arteries. The vascular endothelium is attacked and weakened for years by numerous factors, such as dyslipidemia, hypertension, diabetes, bad lifestyle habits and others (OKUMURA T, et al., 2002). Atherosclerosis manifests itself late most of the time, and can contribute to the occurrence of myocardial infarction, stroke and death, with dyslipidemia being an example of a risk factor (WICK G, et al., 2014). There is an association between atherosclerotic cardiovascular disease, metabolic syndrome, endothelial dysfunction, cardiovascular risk, coronary artery disease and death (TOUSOULIS D, et al., 2014).

Dyslipidemias are disorders of the lipid metabolism in which lipoproteins remaining from these changes have the potential to accumulate in the arterial endothelium, where macrophages can promote the formation of foam cells and subsequently the formation of fatty streaks that result in atherosclerotic plaques (HANDELSMAN Y and SHAPIRO MD, 2017).

In this perspective, dietary interventions have been studied, such as the intake of polyunsaturated fatty acids. The fatty acids of the omega- 6 and omega- 3 families are obtained through the diet or produced by the body from linoleic and alpha-linolenic acids through the action of the enzymes elongase and desaturase. The polyunsaturated fatty acid of the omega-3 (n-3) family, known as alpha-linolenic acid (ALA), allows the formation of two very long chain fatty acids: eicosapentaenoic acid (EPA) and docosahexaenoic acid (DHA). $\mathrm{N}-3$ essential fatty acids are named by the position of the first double bond closest to the methyl terminus of the hydrocarbon chain. EPA and DHA are found in whales, seals, fish oils, cod liver oil and others; but the richest source is fatty fish, such as: mackerel, salmon, trout, herring, tuna and sardines (CALDER PC, 2018).

Adequate consumption of foods sources of omega 3 can benefit vascular and endothelial function, delaying the development of cardiovascular diseases such as arterial stiffness (SANDERS TAB, et al., 2011). Among the beneficial functions of $n-3$, actions have been described in decreasing parameters of the lipid profile, platelet aggregation, heart rate and blood pressure, in addition to anti-inflammatory action. Thus, evidence supports the use of this fatty acid in the prevention of cardiovascular diseases due to improved endothelial function (INNES JK e CALDER PC, 2018; GOODE GK, et al., 1997; SINGHAL A, et al., 2013).

Despite this, the number of studies in humans evaluated as repercussions on endothelial dysfunction is still scarce. Thus, it is necessary to investigate the role that $n-3$ plays in endothelial dysfunction considering the associated lipid profile, inflammation and oxidative stress. 


\section{METHODS}

\section{Data source}

This study is a systematic review that analyzed studies evaluating the effects of $n-3$ supplementation on parameters related to endothelial dysfunction in humans. Healthy patients were included who were diagnosed with dyslipidemia and manifest cardiovascular disease, or no presence of symptoms.

The search of articles was conducted in the electronic databases PubMed, Scopus, Cochrane, and Web of Science by two authors (ALCCS and MGSP) independently. The searches the authors conducted were compared, and the equivalences of the searches and the selection of results were verified. In case of disagreement, the article was evaluated by a third researcher. This review is registered in the International Prospective Register of Systematic Reviews (PROSPERO) database under registration no. CRD42020154536.

\section{Electronic Research}

The study guiding question of this review was defined using the PICO strategy (Patient, Intervention, Comparison, and Outcome), as Table 1 shows. Medical Subject Headings (MeSH) descriptors were used as search terms in the databases using the following Boolean descriptors and operators: ("Fatty Acids, Omega3" or "n3 Fatty Acids" or "n-3 PUFA" or "Omega 3 Fatty Acids" or "n-3Oils") and ("Endothelium" or "Endothelium vascular") and ("Lipid metabolism" or "Lipoproteins" or "Triglycerides" or "Cholesterol") and (“Supplementation”).

Table 1- Steps of the PICO strategy that helped to formulate the study guiding question. Teresina-PI, 2021.

\begin{tabular}{|c|c|c|}
\hline Acronym & Definition & Description \\
\hline P & Population or problem & $\begin{array}{c}\text { Patient diagnosed with dyslipidemia and/or cardiovascular } \\
\text { disease or not manifested. }\end{array}$ \\
\hline I & Intervention & Omega-3 supplementation. \\
\hline C & Comparation & Placebo. \\
\hline $\mathbf{0}$ & Outcomes & $\begin{array}{c}\text { Improvement in markers of endothelial and inflammatory } \\
\text { dysfunction, lipid profile, and global nutritional status. }\end{array}$ \\
\hline
\end{tabular}

Source: Sales ALCC, et al., 2021.

\section{Selection Criteria}

Due to the scarcity of studies related to the theme of this review, there was no time limit for the search for articles, revealing a limitation of this study. The inclusion criteria were I) study population composed of adults and/or the elderly without restriction on ethnicity; II) randomized clinical trial controlled or not by placebo, blind or open; III) studies with participants with dyslipidemia; IV) studies in which the participants used or not lipidlowering drugs; V) studies in which individuals had or were not diagnosed with endothelial dysfunction; and VI) studies in English. Cross-sectional and observational studies, works with animals, and review articles or books were excluded. Figure 1 shows the steps taken in selecting the studies.

\section{Data extraction}

The data extracted from the studies were place of the research, age and gender of participants, sample size, type of supplement used in the supplemented group and placebo, data on the health conditions of individuals, supplementation doses, and outcome. The measurements evaluated were differences between the means of the parameters evaluated.

\section{Risk of Bias Assessment}

In developing this review, we followed PRISMA's recommendations for systematic reviews. The risk of bias of the included studies was assessed using the Cochrane collaboration tool. The risk of bias was classified as high, low, or no risk of bias. 
Figure 1 - Flowchart of research strategy and results. Teresina-PI, 2021.

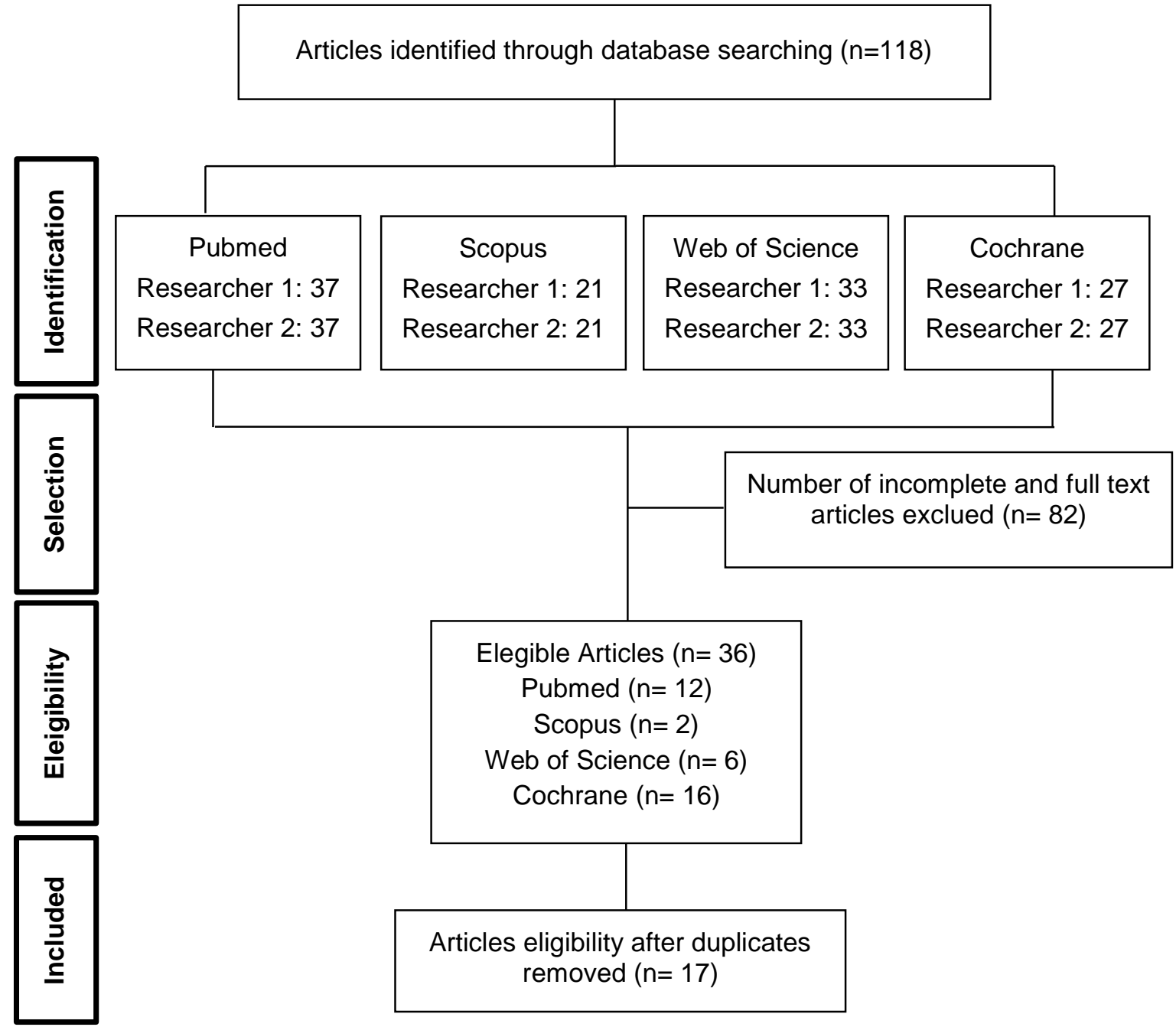

Source: Sales ALCC, et al., 2021.

\section{RESULTS}

We identified 118 articles in the databases defined for the search. After the screening process, we excluded duplicate articles and applied the inclusion criteria. Thereafter, we included 17 articles in this systematic review. Table 2 shows the characteristics of the articles included.

We observed that the population of the studies was predominantly adults of both genders in ten different countries. The duration of supplementation with n-3 ranged between 4 to 25 weeks, with doses of $n-3$ between $0.45 \mathrm{~g}$ and $5.1 \mathrm{~g} /$ day with different proportions of EPA and DHA. The placebo were oils of sunflower, peanut, soybean, palm and corn, in addition to oil and ciprofibrate.

The study by Sanders TAB, et al. (2011) (only study that evaluated dietary consumption) used the Food Frequency Questionnaire (FFQ) as an instrument to assess food intake. The authors used a protocol that requires participants to avoid foods high in fat, caffeine or alcohol the day before and avoid strenuous exercise. It was not clear whether patients received counseling to change their usual diet after participating in the research.

In Tousoulis D, et al. (2014) participants avoided from caffeine, alcohol, smoking and any food for 12 hours; and avoided changes in diet and physical activity habits during study participation. In addition, physical activity and daily dietary records (not specified by the authors) of foods consumed during the study were reviewed to ensure efficacy. 
Table 2 - Characteristics of clinical trials included in this review. Teresina-PI, 2021.

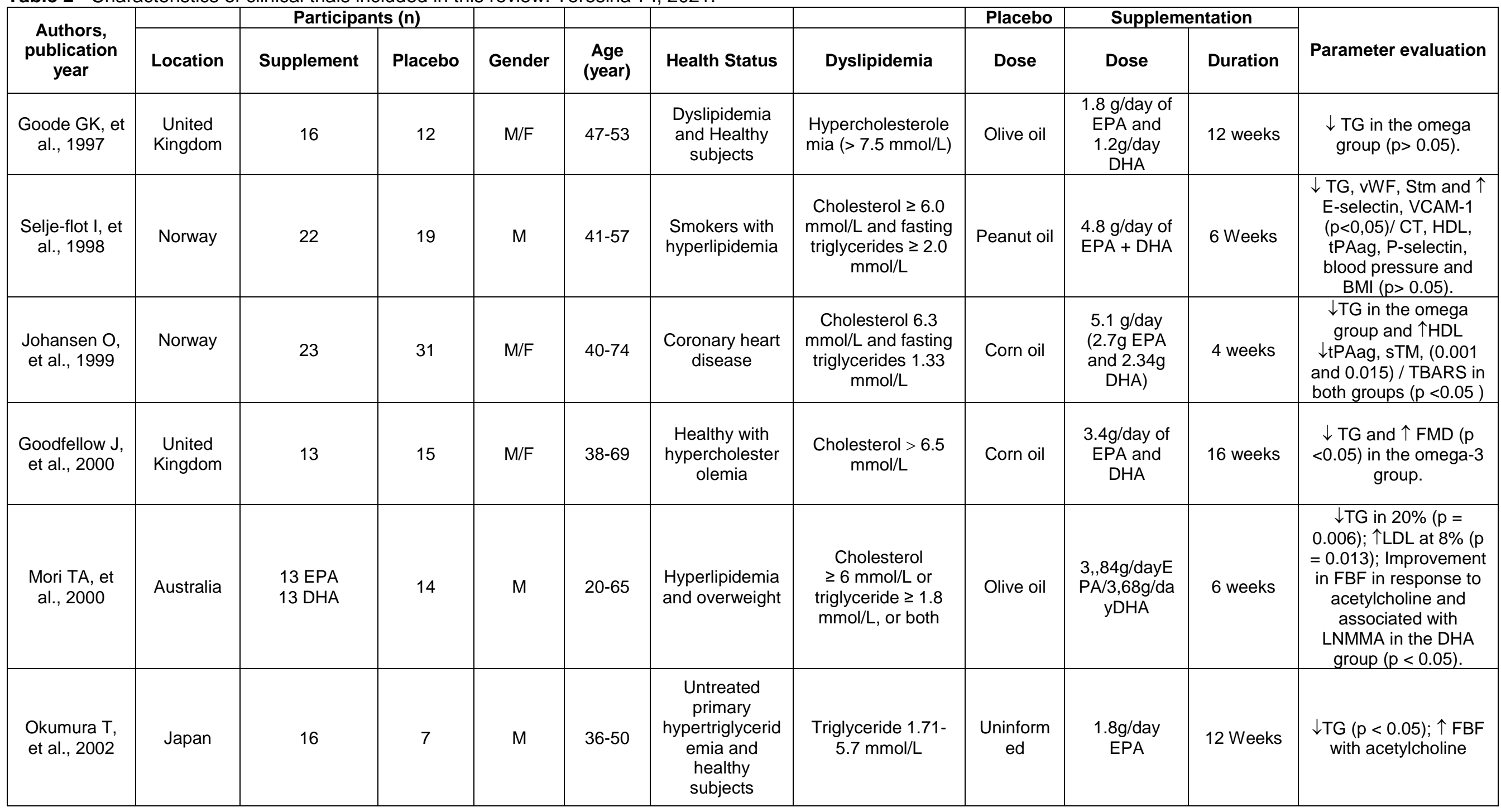




\begin{tabular}{|c|c|c|c|c|c|c|c|c|c|c|c|}
\hline \multirow{2}{*}{$\begin{array}{l}\text { Authors, } \\
\text { publication } \\
\text { year }\end{array}$} & \multirow[b]{2}{*}{ Location } & \multicolumn{2}{|c|}{ Participants (n) } & \multirow[b]{2}{*}{ Gender } & \multirow[b]{2}{*}{$\begin{array}{c}\text { Age } \\
\text { (year) }\end{array}$} & \multirow[b]{2}{*}{ Health Status } & \multirow[b]{2}{*}{ Dyslipidemia } & \multirow{2}{*}{$\begin{array}{c}\text { Placebo } \\
\text { Dose }\end{array}$} & \multicolumn{2}{|c|}{ Supplementation } & \multirow[b]{2}{*}{ Parameter evaluation } \\
\hline & & Supplement & Placebo & & & & & & Dose & Duration & \\
\hline $\begin{array}{l}\text { Thies F, et } \\
\text { al., } 2003\end{array}$ & $\begin{array}{c}\text { United } \\
\text { Kingdom }\end{array}$ & $\begin{array}{l}52 \text { sunflower } \\
53 \text { fish oil }\end{array}$ & 57 & $\mathrm{M} / \mathrm{F}$ & $62-78$ & $\begin{array}{c}\text { Carotid } \\
\text { disease, } \\
\text { Hypertension, } \\
\text { Diabetes } \\
\text { mellitus }\end{array}$ & - & $\begin{array}{l}\text { Soya and } \\
\text { palm oil }\end{array}$ & $\begin{array}{c}6 \\
\text { capsules/day } \\
\text { (1 capsule: } \\
\text { EPA and } \\
\text { DHA = 14:3) }\end{array}$ & $\begin{array}{c}1-25 \\
\text { weeks }\end{array}$ & $\begin{array}{l}\downarrow \text { TG in the omega-3 } \\
\text { group / correlation } \\
\text { between duration of } \\
\text { treatment with omega- } \\
\begin{array}{c}3 \text { and TG }(\rho=-0.44 ; p \\
=0.0118) .\end{array}\end{array}$ \\
\hline $\begin{array}{l}\text { Theobald HE, } \\
\text { et al., } 2007\end{array}$ & $\begin{array}{c}\text { United } \\
\text { Kingdom }\end{array}$ & 38 & 38 & $\mathrm{M} / \mathrm{F}$ & $45-65$ & $\begin{array}{l}\text { Healthy } \\
\text { subjects }\end{array}$ & $\begin{array}{c}\text { Cholesterol } \\
5.4 \mathrm{mmol} / \mathrm{L} \text { and } \\
\text { triglyceride } 1.2 \\
\mathrm{mmol} / \mathrm{L}\end{array}$ & Olive oil & $\begin{array}{c}2.1 \mathrm{~g} / \text { day } \\
\text { DHA }\end{array}$ & $\begin{array}{c}12 \text { Weeks } \\
\text { and } \\
\text { washout of } \\
16 \text { weeks }\end{array}$ & $\downarrow$ diastolic BP \\
\hline $\begin{array}{l}\text { Hill AM, et } \\
\text { al., } 2007\end{array}$ & Australia & 17 & 18 & $\mathrm{M} / \mathrm{F}$ & $25-65$ & $\begin{array}{l}\text { Overweight } \\
\text { with } \\
\text { dyslipidemia } \\
\text { and / or } \\
\text { hypertension } \\
\end{array}$ & $\begin{array}{c}\text { Hypercholesterole } \\
\text { mia }(>5.5 \mathrm{mmol} / \\
\text { L) } \\
\text { Hypertriglyceridemi } \\
\text { a }(>1,6 \mathrm{mmol} / \mathrm{L})\end{array}$ & $\begin{array}{c}\text { Sunflower } \\
\text { oil }\end{array}$ & $\begin{array}{c}0.36 \mathrm{~g} / \mathrm{day} \\
\text { EPA and } \\
1.56 \mathrm{~g} / \mathrm{day} \\
\mathrm{DHA}\end{array}$ & 12 weeks & $\begin{array}{c}\downarrow \mathrm{TG} \text { of } 14 \% ; \uparrow \mathrm{HDL} \text { at } \\
10 \% \text { and } \uparrow \mathrm{FMD}(\mathrm{p} \\
<0.05) .\end{array}$ \\
\hline $\begin{array}{l}\text { Schiano V, et } \\
\text { al., } 2008\end{array}$ & Italy & 16 & 16 & M & $58-73$ & DAP & $\begin{array}{c}\text { Hyperchoresterole } \\
\text { mia }(\geq 62.4 \\
\mathrm{mmol} / \mathrm{L}) / \\
\text { Hypertrigliceridemi } \\
\text { a }(\geq 1.71 \mathrm{mmol} / \mathrm{L})\end{array}$ & $\begin{array}{l}\text { Uninform } \\
\text { ed }\end{array}$ & $\begin{array}{c}\text { 1cap/ day }(1 \\
\mathrm{g}-85 \% \text { of } \\
\text { EPA and } \\
\text { DHA 0.9:1.5) }\end{array}$ & 12 weeks & $\begin{array}{c}\downarrow \text { TG, } \downarrow \text { sTM and } \uparrow \\
\text { FMD in the omega-3 } \\
\text { group ( } p<0.05) / \text { Lipid } \\
\text { profile, MPO and CRP } \\
\quad(p>0.05) .\end{array}$ \\
\hline $\begin{array}{l}\text { Rizza S, et } \\
\text { al., } 2009\end{array}$ & Italy & 26 & 24 & $\mathrm{M} / \mathrm{F}$ & $23-36$ & $\begin{array}{l}\text { Healthy } \\
\text { subjects }\end{array}$ & - & $\begin{array}{l}\text { Refined } \\
\text { olive oil }\end{array}$ & $\begin{array}{c}2 \\
\text { capsules/day } \\
\text { (1 capsule- } \\
\geq 85 \% \text { EPA + } \\
\text { DHA 0.9- } \\
1.5: 1)\end{array}$ & 12 weeks & $\begin{array}{c}\downarrow \mathrm{TG}, \downarrow \text { TNFa and } \uparrow \\
\text { FMD }(\mathrm{p}<0.05) / \uparrow \mathrm{FMD} \\
\text { was associated with } \downarrow \\
\text { TG }(r=-0.452 ; \mathrm{p}= \\
0.02) \text { and TNFa }(r=- \\
0.554 ; \mathrm{p}=0.003) / \mathrm{BMI} \\
\text { and blood pressure } \\
(\mathrm{p}>0.05) .\end{array}$ \\
\hline $\begin{array}{l}\text { Sanders } \\
\text { TAB, et al., } \\
2011\end{array}$ & $\begin{array}{c}\text { United } \\
\text { Kingdom }\end{array}$ & $\begin{array}{l}80-0.45 \mathrm{~g} \\
81-0.9 \mathrm{~g} \\
80-1.8 \mathrm{~g}\end{array}$ & 71 & $\mathrm{M} / \mathrm{F}$ & $45-70$ & $\begin{array}{l}\text { Healthy } \\
\text { subjects }\end{array}$ & - & $\begin{array}{l}\text { Refined } \\
\text { olive oil }\end{array}$ & $\begin{array}{c}\text { Doses of } \\
0.45 \mathrm{~g}, 0.9 \mathrm{~g} \\
\text { and } 1.8 \mathrm{~g} \text { of } \\
\text { EPA + DHA } \\
=1.51: 1\end{array}$ & 24 weeks & $\begin{array}{l}\downarrow \text { TG in the } 1.8 \mathrm{~g} / \mathrm{day} \\
\text { group }(\mathrm{p}<0.014) / \\
\text { Food intake, body } \\
\text { weight, DMF, VOP } \\
(\mathrm{p}>0.05) .\end{array}$ \\
\hline
\end{tabular}




\begin{tabular}{|c|c|c|c|c|c|c|c|c|c|c|c|}
\hline \multirow{2}{*}{$\begin{array}{c}\text { Authors, } \\
\text { publication } \\
\text { year }\end{array}$} & \multirow[b]{2}{*}{ Location } & \multicolumn{2}{|c|}{ Participants (n) } & \multirow[b]{2}{*}{ Gender } & \multirow[b]{2}{*}{$\begin{array}{c}\text { Age } \\
\text { (year) }\end{array}$} & \multirow[b]{2}{*}{ Health Status } & \multirow[b]{2}{*}{ Dyslipidemia } & \multirow{2}{*}{$\begin{array}{c}\text { Placebo } \\
\text { Dose }\end{array}$} & \multicolumn{2}{|c|}{ Supplementation } & \multirow[b]{2}{*}{ Parameter evaluation } \\
\hline & & Supplement & Placebo & & & & & & Dose & Duration & \\
\hline $\begin{array}{l}\text { Koh KK, et } \\
\text { al., } 2012\end{array}$ & Coreia & 50 & 49 & $\mathrm{M} / \mathrm{F}$ & $54-55$ & $\begin{array}{c}\text { Hypertriglycerid } \\
\text { emia }\end{array}$ & $\begin{array}{l}\text { Hypertriglyceridemi } \\
\mathrm{a}(>1.71 \mathrm{mmol} / \mathrm{L})\end{array}$ & $\begin{array}{l}\text { Uninform } \\
\text { ed }\end{array}$ & $\begin{array}{c}0.92 \mathrm{~g} / \text { day } \\
\text { EPA and } \\
0.76 \mathrm{~g} / \mathrm{day} \\
\text { DHA }\end{array}$ & 8 weeks & $\begin{array}{c}\downarrow \mathrm{TG} \text { and TG/HDL } \\
\text { ratio and } \uparrow \mathrm{FMD}(\mathrm{p} \\
<0.05) / \mathrm{BMI} \text { and CRP } \\
(\mathrm{p}>0.05) .\end{array}$ \\
\hline $\begin{array}{l}\text { Doenyas- } \\
\text { Barak K, et } \\
\text { al., } 2012\end{array}$ & Israel & 32 & 46 & M & $30-70$ & $\begin{array}{l}\text { Hypercholester } \\
\text { olemia } \\
\text { routinely } \\
\text { treated by } \\
\text { statins }\end{array}$ & $\begin{array}{c}\text { Cholesterol } \\
40.04 \mathrm{mmol} / \mathrm{L} \text { and } \\
\text { triglyceride } 1.37 \\
\mathrm{mmol} / \mathrm{L}\end{array}$ & Soya oil & $\begin{array}{c}1.08 \mathrm{~g} / \mathrm{day} \\
\mathrm{EPA} \text { and } \\
0.816 \mathrm{~g} / \mathrm{day} \\
\mathrm{DHA}\end{array}$ & 23 Weeks & $\begin{array}{l}\text { lipid profile }(p>0.05) ; \downarrow \\
\text { IL-6 and diastolic BP } \\
\text { after } 20 \text { weeks } \\
(p<0.05) .\end{array}$ \\
\hline $\begin{array}{l}\text { Singhal A, et } \\
\text { al., } 2013\end{array}$ & London & 162 & 162 & $\mathrm{M} / \mathrm{F}$ & $18-37$ & $\begin{array}{l}\text { Healthy } \\
\text { subjects }\end{array}$ & $\begin{array}{c}\text { Cholesterol } \\
2.4 \mathrm{mmol} / \mathrm{L} \text { and } \\
\text { triglyceride } 0.8 \\
\mathrm{mmol} / \mathrm{L}\end{array}$ & Olive oil & $\begin{array}{c}1.6 \mathrm{~g} / \text { day } \\
\mathrm{DHA} /\end{array}$ & 16 weeks & $\begin{array}{c}\downarrow T G \text { and VLDL and } \\
\text { FMD }(p<0.05) / \text { Lipid } \\
\text { profile, BMl and CRP } \\
(p>0.05) .\end{array}$ \\
\hline $\begin{array}{l}\text { Tousoulis D, } \\
\text { et al., } 2014\end{array}$ & Grécia & 15 & 14 & $\mathrm{M} / \mathrm{F}$ & $26-70$ & MetS & $\begin{array}{c}\text { Hypertriglyceridemi } \\
a \\
(>1.71- \\
5.69 \mathrm{mmol} / \mathrm{L})\end{array}$ & $\begin{array}{l}\text { Uninform } \\
\text { ed }\end{array}$ & $\begin{array}{c}2 \mathrm{~g} / \text { day }(0,92 \\
\mathrm{g} \text { of EPA } \\
\text { and } 0,76 \mathrm{~g} \text { of } \\
\text { DHA })\end{array}$ & $\begin{array}{l}4 \text { Weeks } \\
\text { and } \\
\text { washout of } \\
8 \text { weeks }\end{array}$ & $\begin{array}{c}\downarrow \text { TG, CT, LDL (p } \\
<0.001) ; \downarrow \text { PWV and } \uparrow \\
\text { FMD }(p<0.05) ; \downarrow \text { IL-6 } \\
\text { and } \uparrow \text { PAI-1 }(p \\
<0.001) / \text { BMI }(p>0.05) .\end{array}$ \\
\hline $\begin{array}{l}\text { Casanova } \\
\text { MA, et al., } \\
2016\end{array}$ & Brazil & 29 & 29 & $\mathrm{M} / \mathrm{F}$ & $40-65$ & $\begin{array}{c}\text { Hypertension } \\
\text { at low and high } \\
\text { cardiovascular } \\
\text { risk }\end{array}$ & $\begin{array}{c}\text { Triglycerides } 1.71- \\
5.69 \mathrm{mmol} / \mathrm{L}\end{array}$ & $\begin{array}{c}\text { Ciprofibra } \\
\text { te }\end{array}$ & $\begin{array}{c}1.8 \mathrm{~g} / \mathrm{day} \\
(60 \% \mathrm{EPA} \\
\text { and } 40 \% \\
\text { DHA })\end{array}$ & 12 Weeks & $\begin{array}{c}\downarrow T G \text { and VOP, and } \\
\uparrow F M D \text { in patients with } \\
\text { high and low risk of } \\
\text { CVD ( } p<0.05) / B M I, \\
\text { WC, blood pressure } \\
(p>0.05) .\end{array}$ \\
\hline
\end{tabular}

Subtitle: $\mathrm{EPA}=$ eicosapentaenoic acid; $\mathrm{DHA}=$ docosahexaenoic acid; $\mathrm{TG}=$ triglycerides; $\mathrm{LDL}=$ low density lipoprotein; $\mathrm{CT}=\mathrm{cholesterol}$; $\mathrm{HDL}=$ high density lipoprotein; $\mathrm{VLDL}=$ very low density lipoprotein; $\mathrm{STM}=$ thrombomodulin; $\mathrm{vWF}=$ ville factor; tPAag $=$ tissue plasminogen activating antigen; $E$-selectin and $P$-selectin $=$ soluble forms of cell adhesion molecules, $\mathrm{VCAM}-1=$ vascular adhesion molecule; FMD = dilation mediated by the brachial artery flow; FBF = blood flow from the forearm; PWV $=$ pulse wave speed; $\mathrm{BP}=$ blood pressure; $\mathrm{CRP}=\mathrm{C}$-reactive protein; $\mathrm{MPO}=$ myeloperoxidase; IL-6 = interleukin $6 ; \mathrm{PAl}-1$ = plasminogen activator inhibitor 1 ; $\mathrm{BMI}=$ body mass index; LNMMA = NG-monomethyl-L-arginine; PWV = pulse wave velocity; MetS = metabolic syndrome.

Source: Sales ALCC, et al., 2021. 


\section{Risk of bias in the included studies}

Figure 2 shows the assessment of risk of bias in the studies included in this review. The studies included had an $82.4 \%(14 / 17)$ of no risk of bias based according to the methods we used to generate the randomization sequence. For the sequence of allocation and blinding of outcome evaluators, there was a no risk of bias in $64.7 \%(11 / 17)$ and $88.2 \%(15 / 17)$, respectively.

Considering performance bias, $82.4 \%$ (14/17) of the studies had a low risk of bias considering the blinding of study participants and professionals. The friction bias detected a low risk, with $70.8 \%(12 / 17)$ in studies considering correctly all losses or exclusions for each outcome.

The selective outcome report had an adequate $94.1 \%$ value (16/17), indicating that the clinical trials made it clear that the results of interest were reported according to the proposed methods. Finally, for the other biases, they were $100 \%$ with low risk of bias.

\section{Effects of supplementation with n-3 fatty acids on lipid profile parameters}

Of the 16 studies that evaluated the lipid profile, 13 had statistically significant reductions in serum triglyceride concentrations (TG) in response to supplementation with $n-3$ polyunsaturated fatty acids at doses ranging from 1 to $5.1 \mathrm{~g} /$ day. Of these, nine studies were conducted with groups of dyslipidemic patients or patients with other risk factors for cardiovascular diseases. It is noteworthy that the supplementation time varied between six and 25 weeks in studies that found a reduction in this parameter.

For serum concentrations of low-density lipoprotein (LDL), Mori TA, et al. (2000) found an $8 \%$ increase in serum LDL concentrations in the group supplemented with DHA alone (four capsules / day; $92 \%$ DHA) for six weeks. In contrast, Tousoulis D, et al. (2014) found a significant reduction in LDL after 12 weeks with $2 \mathrm{~g} /$ day (46\% EPA and $38 \%$ DHA in one capsule).

Regarding the other parameters, such as high-density lipoprotein (HDL), the study of Hill AM, et al. (2007) showed a 10\% increase in serum HDL concentrations with doses of $6 \mathrm{~g} / \mathrm{day}(360 \mathrm{mg} / \mathrm{day}$ of EPA and 1560 $\mathrm{mg} /$ day of $\mathrm{DHA}$ ) for 12 weeks. Considering serum concentrations of very low-density lipoprotein (VLDL), there were only significant reductions in the findings of Singhal A, et al. (2013), who used supplements of eight capsules/day (1600 mg/day of DHA) for 16 weeks.

Figure 2- Methodological quality of included studies. Teresina-PI, 2021.

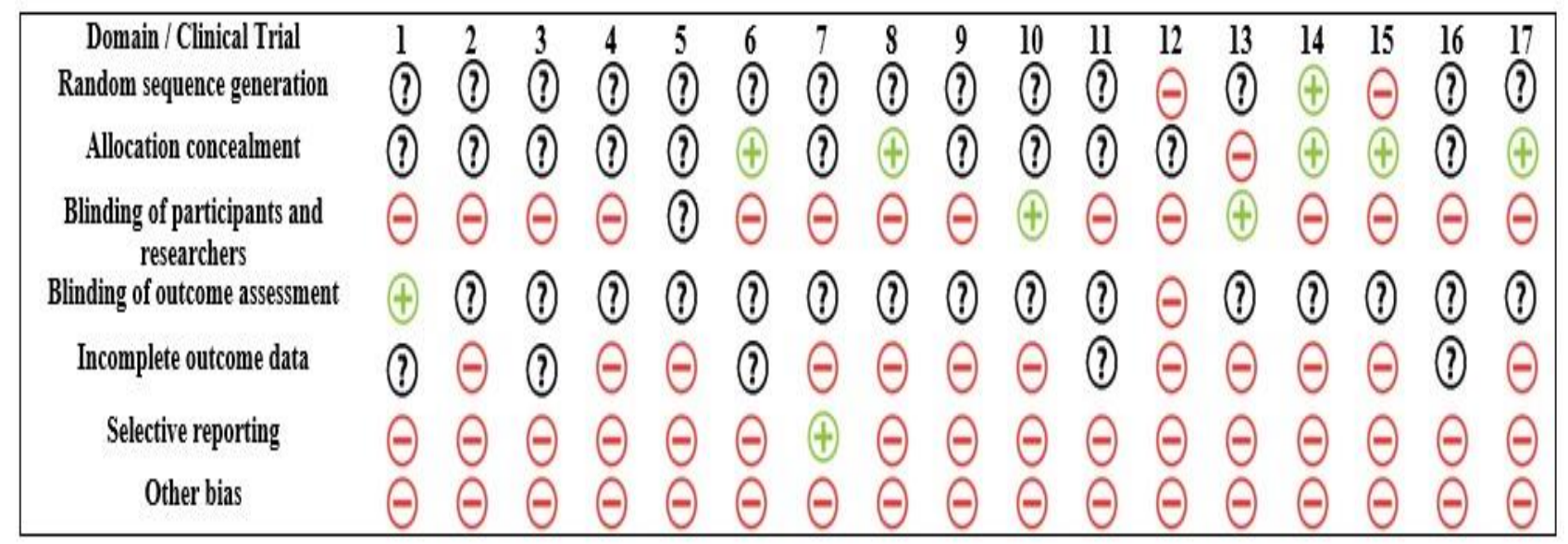

Subtitle: $\Theta$ Low risk; (3) Of bias; $\oplus$ High risk of bias; Unclear risk of bias / Goode GK, et al., 1997(1); Seljeflot I, et al., 1998(2); Johansen O, et al., 1999(3); Goodfellow J, et al., 2000(4); Mori TA, et al., 2000(5); Okumura T, et al., 2002(6); Thies F, et al., 2003(7); Theobald HE, et al., 2007(8); Hill AM, et al., 2007(9); Schiano V, et al., 2008(10); Rizza S, et al., 2009(11); Sanders TAB, et al., 2011(12); Koh KK, et al., 2012(13); DoenyasBarak K, et al., 2012(14); Singhal A, et al., 2013(15); Tousoulis D, et al., 2014(16); Casanova MA, et al., 2016(17). Source: Sales ALCC, et al., 2021. 


\section{Effects of supplementation with n-3 fatty acids on markers of inflammation and lipid peroxidation}

As for inflammatory markers in any of the six studies included in this review that assessed these parameters, there were no changes in serum C-reactive protein (CRP) in response to the applied interventions. In relation to other markers, Rizza S, et al. (2009) observed a decrease in the concentration of plasma tumor necrosis factor (TNFa), as well as a TG reduction in healthy adult patients with supplementation of $2 \mathrm{~g} /$ day of $\mathrm{n}-3$ for 12 weeks.

For IL-6, Doenyas-Barak K, et al. (2012) should decrease his recommendations after 20 weeks of treatment with $1,084 \mathrm{mg}$ of EPA and $816 \mathrm{mg}$ of DHA per day for patients with statin-treated hypercholesterolemia.

Regarding the markers of lipid peroxidation, Johansen O, et al. (1999) evaluated thiobarbituric acid reactive species (TBARS) and found no differences in the values after four weeks of supplementation with $5.1 \mathrm{~g} /$ day of EPA and DHA. Schiano V, et al. (2008) evaluated the concentrations of myeloperoxidase (MPO) of patients with peripheral arterial disease and did not observe a significant reduction in this parameter with supplementation of $1 \mathrm{~g}$ for 12 weeks.

\section{Effects of supplementation with n-3 fatty acids on blood pressure and global nutritional status}

Seven studies evaluated the overall nutritional status, as determined by body mass index (BMI), and reported no significant differences between the groups and intervention times. Casanova MA, et al. (2017) reported no differences in waist circumference (WC) between hypertensive patients who were at a low or at a high risk of cardiovascular disease with supplementation of n-3 fatty acids (1800 mg/day) for 12 weeks.

Blood pressure was evaluated in six trials. Theobald HE, et al. (2007) analyzed 38 healthy men and women between aged 40 and 65, divided in a group receiving n-3 and another receiving olive oil, each phase of treatment lasting three months, separated by a washout period of four months. Only these authors reported that supplementation with $2.1 \mathrm{~g} /$ day of DHA for 12 weeks and 16 weeks of washout reduced diastolic blood pressure in the supplemented group.

\section{Effects of supplementation with n-3 fatty acids on markers of endothelial dysfunction}

One of the markers of endothelial dysfunction assessed in nine studies was dilation mediated by brachial artery flow (FMD). In seven cases Goodfellow J, et al. (2000); Hill AM, et al. (2007); Schiano V, et al. (2008); Rizza S, et al. (2009); Koh KK, et al. (2012); Tousoulis D, et al. (2014); Casanova MA, et al. (2016) there was a significant increase $(p<0.05)$ in FMD in groups supplemented with at least $1 \mathrm{~g}$ of EPA and DHA for a minimum of 12 weeks.

Noteworthy is the research by Rizza S, et al. (2009). The authors showed increased levels of FMD. The authors associated this result with a reduction in the serum concentrations of TG and TNF when healthy adult patients were supplemented with $2 \mathrm{~g} /$ day of $\mathrm{n}-3$ for 12 weeks.

For adhesion molecules, the results of Seljeflot I, et al. (1998) markedly increased E-selectin and vascular adhesion molecule 1 (VCAM-1) $(p<0.005)$ in patients with hyperlipidemia supplemented with $4.8 \mathrm{~g} /$ day of EPA with DHA for six weeks. Similar to this study, Johansen O, et al. (1999) useful tips for E-selectin and VCAM-1 in a 4-week washout in the placebo group that took $5.1 \mathrm{~g} /$ day of $n-3$ in this phase of the study.

Pulse wave velocity (PWV) was considered in the works of Tousoulis D, et al. (2014) and Casanova MA, et al. (2016). The authors found a significant reduction in this parameter when supplemented with 2 $\mathrm{g} /$ day and $1.8 \mathrm{~g} /$ day both for 12 weeks, respectively.

Considering forearm blood flow (FBF), Mori TA, et al. (2000) observed an improvement in this parameter in response to acetylcholine and also to a co-infusion of acetylcholine associated with NG-monomethyl-Larginine (LNMMA) in patients with hypertriglyceridemia supplemented with DHA (four capsules/day, $92 \%$ DHA) $(p<0.05)$ for six weeks.

In addition, Okumura T, et al. (2002) reported an increase in FBF response with acetylcholine with 1800 $\mathrm{mg} /$ day EPA supplementation for 12 weeks in patients with hypertriglyceridemia. 


\section{DISCUSSION}

We conducted this systematic review to investigate the effects of $n-3$ supplementation on endothelial dysfunction in humans considering lipid profile, inflammatory markers, lipid peroxidation, and global nutritional status.

In the present study, we found a reduction in serum TG levels. This result can be attributed to the actions of EPA and DHA in reducing hepatic secretion of very low-density lipoprotein cholesterol (VLDL-c) and increasing hepatic $\beta$-oxidation, resulting in less availability of fatty acids available for TG synthesis. At the same time, they regulate apoliprotein B-100, which is necessary for the formation of VLDL-C, causing a decrease in its production and liver secretion (BACKES J, et al., 2016).

Considering low-density lipoprotein cholesterol (LDL-c) concentrations, EPA and DHA have different effects on LDL-c. Mori TA, et al. (2000) found that the increase of this lipoprotein, when supplemented with DHA for six weeks, in patients with hyperlipidemia; this increase did not occur in the group supplemented with EPA. We observed that DHA has the role of reducing the synthesis of ApoC3, in relation to EPA, by means of liver transcription factors such as FOX-O1, resulting in the hydrolysis of VLDL-C. With this, there was an increase in the conversion of LDL-c into larger fluctuating and less atherogenic particles (DAVIDSON MH, 2013).

We observed that EPA and DHA can help to increase high-density lipoprotein cholesterol (HDL-C) concentrations. This can be explained by the inhibition of cholesterol transport protein (CETP) with a decrease in lipid synthesis. Hill AM, et al. (2007) observed this with a supplementation of $6 \mathrm{~g} /$ day $(360 \mathrm{mg} /$ day of EPA and $1,560 \mathrm{mg} /$ day of DHA) (INNES JK e CALDER PC, 2018).

Regarding possible anti-inflammatory effects, the findings of this review reveal that $n-3$ can reduce the concentrations of inflammatory cytokines such as IL- 6 and TNF- $\alpha$. This happened with supplementation of at least $2 \mathrm{~g} /$ day for at least 12 weeks. Rizza S, et al. (2009) stated that EPA and DHA can increase the incorporation of eicosanoids, causing a better fluidity in membranes, in addition to the metabolism of series -3 prostaglandins, thromboxanes, and series- 5 leukotrienes. Therefrom, it is possible to modulate the synthesis of TNF- $\alpha$ by decreasing the activity of the converting enzyme (TACE).

In addition, EPA and DHA also act to reduce inflammation through the mechanism of inactivation of the transcription factor NF-KB, which can be induced by lipoprotein lipase (LPS) and Toll-like receptor (TLR-4), as well as by activation of the receptor activated by peroxisome proliferators (PPAR-y), causing a decrease in the phosphorylation capacity of $\mathrm{IkB}$ and inhibiting the production of pro-inflammatory cytokines, adhesion molecules, cyclooxygenase 2 (COX-2), and nitric oxide synthase (iNOS) (CALDER PC, 2017; SERHAN CN e PETASIS NA, 2011).

The results Seljeflot I, et al. (1998) and Johansen O, et al. (1999) reported suggest that $n-3$ cannot reduce the concentrations of the adhesion molecules E-selectin and VCAM-1 when supplemented with 4.8 and 5.1 $\mathrm{g} /$ day of EPA and DHA for six and four weeks, respectively. The increases in these molecules may be related to vascular and inflammatory lesions, as they are early markers of endothelial activation (STORCH AS, et al., 2017).

Regarding lipid peroxidation products, there were no significant reductions with $\mathrm{n}-3$ supplementation when authors evaluated TBARS at a dose of $5.1 \mathrm{~g} /$ day of EPA with DHA (JOHANSEN O, et al., 1999). Despite the benefits of eating $n-3$ fatty acids for oxidative stress, there is a possibility of increased lipid peroxidation when there is an increase in the number of unsaturations with the insertion of EPA and DHA, generating free radicals and oxidized LDL-c, which can explain the results of this research (NENSETER MS and DREVON CA, 1996).

For MPO concentrations, there were no satisfactory results when supplemented with $1 \mathrm{~g} /$ day. Based on this, Schiano V, et al. (2008) claim that high levels of MPO can convert LDL into an atherogenic form, generating reactive oxygen species and reducing concentrations of nitric oxide (NO). This may be related to severity and poor prognosis of coronary heart disease.

Regarding the global nutritional status, no studies analyzed in this review found significant changes in parameters such as BMI. This is a non-specific and insensitive method to detect changes in body fat. It is 
important to emphasize that adiposity can increase the risk of endothelial changes due to the production of inflammatory adipokines, infiltration of macrophages, and consequently in the increase in the production of free radicals (TODORČEVIĆ M and HODSON L, 2016).

Considering endothelial dysfunction markers, there was a significant increase in FMD values. This parameter is considered one of the first reversible manifestations of vascular diseases. In addition, there was an improvement in FBF associated with acetylcholine and LNMMA with n-3 supplementation. The DHA seems to affect specifically the increase in the release of vasodilators such as prostanoids and endothelial hyperpolarizing factors (MORI TA, et al., 2000; STORCH AS, et al., 2017).

Another marker of endothelial dysfunction is PWV, which has caused significant reductions in its values. Casanova MA, et al. (2016) pointed out that this marker may have been different in their study, as n-3 supplementation seems to attenuate arterial stiffness by reflecting on a more elastic and healthier vessel.

It should be noted that supplementation with n-3 fatty acids may be able to change the fluidity of the membrane of endothelial cells, causing an increase in the synthesis and/or release of vaso dilating agents such as NO, in addition to incorporating phospholipids by arachidonic acid. This process reduces the absorption of omega- 6 , providing a balance in the proportion of omega- 6 and $n-3$ and the production of eicosanoids (CALDER PC, 2017; GOODFELLOW J, et al., 2000; KOH KK, et al., 2012; SCHIANO V, et al., 2008).

This is the first systematic review that aims to evaluate the effects of $n-3$ supplementation on the parameters of endothelial dysfunction in humans. We observed that the studies do not present a standardization regarding the dose offered per day of $n-3$, nor the composition of EPA and DHA contained in the capsules administered to patients. In addition, different age groups and health conditions that may influence some studied parameters were included in this review.

In addition, we conducted a search with different populations, such as adults and the elderly, and with different health conditions, such as healthy, dyslipidemic, overweight, metabolic syndrome, diabetic, and coronary heart disease that can influence some parameters studied.

\section{FINAL CONSIDERATIONS}

The results of this systematic review show the benefits of $n-3$ supplementation in decreasing TG, VLDL-c, TNF- $\alpha$ and IL- 6 and improving HDL-C, FMD, FBF and PWV with better results with 12 weeks of intervention. Despite the positive results, clinical studies are still needed to elucidate the protective role that this nutrient has in the studied parameters. We cannot yet establish a specific dose to achieve the benefits reported in this review, as the effects may depend not only on the dose, but also on the composition, the time of intervention and the associated risk factors.

\section{REFERENCES}

1. ALLEN JD, et al. Nitrite and nitric oxide metabolism in peripheral artery disease. Nitric Oxide, 2012; 26(4): $217-222$.

2. BACKES J, et al. The clinical relevance of omega-3 fatty acids in the management of hypertriglyceridemia. Lipids in Health and Disease, 2016; 15: 118.

3. CALDER PC. Omega-3 fatty acids and inflammatory processes: from molecules to man. Biochemical Society Transactions, 2017; 45(5): 1105-1115.

4. CALDER PC. Very long-chain $n-3$ fatty acids and human health: fact, fiction and the future. Proceedings of the Nutrition Society, 2018; 77: 52-72.

5. CASANOVA MA, et al. Omega-3 fatty acids supplementation improves endothelial function and arterial stiffness in hypertensive patients with hypertriglyceridemia and high cardiovascular risk. Journal of the American Society of Hypertension, 2016; 11(1): 10-19.

6. DAVIDSON MH. Omega-3 fatty acids: new insights into the pharmacology and biology of docosahexaenoic acid, docosapentaenoic acid, and eicosapentaenoic acid. Current Opinion in Lipidology, 2013; 24(6): 467-474.

7. DOENYAS-BARAK $\mathrm{K}$, et al. N-3 fatty acid supplementation to routine statin treatment inhibits platelet function, decreases patients' daytime blood pressure, and improves inflammatory status. European Journal of Clinical Pharmacology, 2012; 68(8): 1139-1146. 
8. GOODE GK, et al. Dietary supplementation with marine fish oil improves in vitro small artery endothelial function in hypercholesterolemic patients: a double-blind placebo-controlled study. Circulation, 1997; 96(9): 2802-2807.

9. GOODFELLOW J, et al. Dietary supplementation with marine omega-3 fatty acids improve systemic large artery endothelial function in subjects with hypercholesterolemia. Journal of the American College of Cardiology, 2000; 35(2): 265-270.

10. HANDELSMAN Y, Shapiro MD. Triglycerides, atherosclerosis, and cardiovascular outcome studies: focus on omega3 fatty acids. Endocrine practice, 2017; 23(1): 100-112.

11. HILL AM, et al. Combining fish-oil supplements with regular aerobic exercise improves body composition and cardiovascular disease risk factors. The American Journal of Clinical Nutrition, 2007; 85(5): 1267-1274.

12. INNES JK, Calder PC. The differential effects of eicosapentaenoic acid and docosahexaenoic acid on cardiometabolic risk factors: a systematic review. International Journal of Molecular Sciences, 2018; 19(2): 532.

13. JOHANSEN O, et al. The Effect of Supplementation with Omega-3 Fatty Acids on Soluble Markers of Endothelial Function in Patients with Coronary Heart Disease. Arteriosclerosis, Thrombosis, and Vascular Biology, 1999; 19(7): 1681-1686.

14. KOH KK, et al. Significant differential effects of omega-3 fatty acids and fenofibrate in patients with hypertriglyceridemia. Atherosclerosis, 2012; 220(2): 537-544.

15. MORI TA, et al. Differential effects of eicosapentaenoic acid and docosahexaenoic acid on vascular reactivity of the forearm microcirculation in hyperlipidemic, overweight men. Circulation, 2000; 102(11): 1264-1269.

16. nenseter MS, DREVON CA. Dietary polyunsaturates and peroxidation of low density lipoprotein. Current Opinion in Lipidology, 1996; 7: 8-13.

17. OKUMURA T, et al. Eicosapentaenoic Acid Improves Endothelial Function in Hypertriglyceridemic Subjects Despite Increased Lipid Oxidizability. The American Journal of the Medical Sciences, 2002; 324(5): 247-253.

18. QIAN J, FULTON D. Post-translational regulation of endothelial nitric oxide synthase in vascular endothelium. Frontiers in Physiology, 2013; 4(347).

19. RIZZA S, et al. Fish oil supplementation improves endothelial function in normoglycemic offspring of patients with type 2 diabetes. Atherosclerosis, 2009; 206(2): 569-574.

20. SANDERS TAB, et al. Effect of low doses of long-chain n-3 PUFAs on endothelial function and arterial stiffness: a randomized controlled trial. The American Journal of Clinical Nutrition, 2011; 94(4): 973-980.

21. SCHIANO V, et al. Omega-3 polyunsaturated fatty acid in peripheral arterial disease: Effect on lipid pattern, disease severity, inflammation profile, and endothelial function. Clinical Nutrition, 2008; 27(2): 241-247.

22. SELJEFLOT I, et al. Effects of omega-3 fatty acids and/or antioxidants on endothelial cell markers. European Journal of Clinical Investigation, 1998; 28(8): 629-635.

23. SERHAN CN, PETASIS NA. Resolvins and protectins in inflammation-resolution. Chemical Reviews, 2011; 111(10): $5922-5943$.

24. SINGHAL A, et al. Docosahexaenoic acid supplementation, vascular function and risk factors for cardiovascular disease: a randomized controlled trial in young adults. Journal of the American Heart Association, 2013; 2(4): e000283.

25. STORCH AS, et al. Methods of endothelial function assessment: description and applications. International Journal of Cardiovascular Sciences, 2017; 30(3): 262-273.

26. THEOBALD HE, et al. Low-dose docosahexaenoic acid lowers diastolic blood pressure in middle-aged men and women. The Journal of Nutrition, 2007; 137(4): 973-978.

27. THIES F, et al. Association of $n-3$ polyunsaturated fatty acids with stability of atherosclerotic plaques: a randomised controlled trial. The Lancet, 2003; 361: 477-485.

28. TODORČEVIĆ M, HODSON L. The effect of marine derived $n-3$ fatty acids on adipose tissue metabolism and function. Journal of Clinical Medicine, 2016; 5(1): 3.

29. TOUSOULIS D, et al. Omega-3 PUFAs improved endothelial function and arterial stiffness with a parallel antiinflammatory effect in adults with metabolic syndrome. Atherosclerosis, 2014; 232: 10-16.

30. WICK G, et al. The role of heat shock proteins in atherosclerosis. Nature Reviews Cardiology, 2014; 11: 516-529. 